\title{
From Apartheid to Globalisation: Health and Social Change in South Africa
}

\author{
Mickey Chopra and David Sanders
}

\section{Introduction}

\begin{abstract}
Outh Africa's transition from a racist apartheid society that denied basic - human rights to a majority of its population to a fully democratic nation is one of the more celebrated transitions of recent times. However this transition is having its costs as it has also involved an acceleration of the integration of South Africa into the global economy and a stripping away of many of the protective trade barriers that cocooned the South African economy. The freedom of movement resulting from the scrapping of apartheid laws and a neo-liberal macro-economic policy has led to rapid urbanization, increasing unemployment and deepening inequalities. As was the case in $19^{\text {th }}$ Century Europe South Africa is suffering a significant rise in mortality, especially amongst young men and women.

This paper briefly summarises the economic, social and political transitions that South Africa has gone through in the last decade. It then highlights some of impacts this transition has had on mortality. The last section explores the parallels between the impact of the recent South African transition and that which occurred in industrializing Europe. The paper concludes with a discussion on the prospects of South Africa enjoying the same development trajectory as that of $19^{\text {th }}$ Century Europe.
\end{abstract}

\section{Poverty and inequality in South Africa}

South Africa's political transition from the racist apartheid state to a fully democratic country is well documented. Perhaps less appreciated is how this political transition was driven by an imperative to save an economy that had been in crisis since the mid 1970s. This section will give a brief historical overview 
leading up to the historical elections of 1994. It will then sketch the political and economic transitions that have occurred since that time.

The victory of the Nationalist Party in 1948 ushered in the apartheid state that systematically discriminated against the majority black population. Some commentators have pointed out that the new regime merely codified a practice that had been going on for many years. ${ }^{1}$ For example the 1913 Native Land Act had designated $13 \%$ of the available land as the only areas in which the black population could purchase and reside in. But there is little doubt that the accession to power of the Nationalist Party signified the victory of a particular Afrikaner nationalist ideology. There has been much written about the political and ideological nature of apartheid; however less prominent is the useful role this political superstructure played for Afrikaner capital in South Africa during this time. The post war South African economy was dominated by the mineral and agricultural sectors that depended upon a regular supply of cheap and relatively unskilled labour that the apartheid laws were able to supply. The apartheid state actively assisted in the supply of such labour:

'Massive forced removals saw the labour tenant system replaced by a contract labour system. Between 1960 and 1982, 3,5 million people were forcibly removed by the state. About 700,000 more people were removed from urban areas declared 'white".'.

The creation of 'Homeland' areas served as dumping grounds for unemployed labour and allowed its cheap reproduction of labour. This policy also served as a useful way of diffusing and marginalizing any discontent. Strict influx control measures prevented Africans from being physically present in many urban centers. Under this apartheid institutional framework, the market acted 'like a malevolent invisible hand, working to the advantage of white workers and capitalists, and widening the wage differentials between black and white workers' ${ }^{3}$ The ratio of per capita incomes of white to black people rose from 10.6:1 in 1947 to 15:1 in $1970{ }^{4}$

The economic model began to falter after the oil crisis in 1973. An important cause was the lack of a large enough skilled and stable workforce as recognized by Harry Openheimer, chair of the largest conglomerate in South Africa:

"Prospects for economic growth will not be attained so long as a majority of the population is prevented by lack of education and technical training or by positive

1 H. Marais, South Africa: Limits to change - the political economy of transformation (Cape Town, UCT Presss, 1998).

2 Marais, (1998), p.22.

3 M. McGarth, 'Economic growth, income distribution and social change' in The Political Economy of South Africa, eds. N. Natrass and E. Ardington (Cape Town, Oxford University Press, 1990), 92.

4 McGarth, (1990), p.94. 
prohibition from playing the full part of which it is capable in the national development". 5

The 1970s and 80s also witnessed the rise of mass resistance, first from unionized workers (with huge strikes in the mid-1970s) and, when these were crushed, a growing urbanized proletariat. This latter movement was marked by a large degree of spontaneity and the lack of control or direction by national bodies such as the African National Congress. Street committees and youth groups replaced the state in many areas, though quite often they were ephemeral and not structured enough to be legitimized by the majority of people living in the areas. ${ }^{6}$

By the early nineties the economy was in negative growth with high rates of capital flight out of the country and high levels of unemployment. The strategy of primary product export and import substitution had foundered on the rocks of unstable primary product prices, shortage of skilled labour and lack of a large enough domestic market. The situation was compounded by the huge costs of maintaining the apartheid apparatus. In addition to the high military and security expenditures there was the cost of the bureaucracy:

"By 1985 the political system had given birth to 13 Houses of Parliament... Occupying seats in these 13 bodies were 1270 members. Each of these legislative organs had executive structures, which by 1985 had spawned 151 departments. These included 18 Departments of Health and Welfare; 14 Departments of Education... Finally, these Departments were responsible to 11 Presidents, Prime Ministers or Chief Ministers in South Africa."”

\section{Economic Policy}

It was quite clear that there would need to be a profound change in the political and social structure of South Africa. Limited space does not allow for a description of the negotiated settlement. Suffice it to say that although there was a successful political transition to a majority government the dominant global political and economic forces played a significant role in shaping its political and economic strategy.

In the flurry of post-apartheid policy formulation two macroeconomic alternatives began to take shape. A group of economists within the ANC itself presented a policy that sought 'growth through redistribution of wealth'. At its

5 Cited in S. Gelb, South Africa's economic crisis (London, Zed Books, 1991).

6 S. Friedman, 'The Struggle within the Struggle: South African resistence strategies', Transformation, No. 3 (Durban, 1987).

7 F. Van Zyl Slabbert, The quest for democracy: South Africa in transition (London, Penguin Books, 1992). 
heart was a relatively modest role for the state to initially invest in building public infrastructure and strategic interventions to assist key industries. The other serious policy option was put forward by the South Africa Foundation (which derived most of its support from the business community). This advocated a neo-liberal approach with a streamlining of state functions and expenditure, privatization and deregulation of the financial sector. It was envisaged that this would lead to growth through the attraction of foreign direct investment and redistribution would occur through the 'trickle down' of wealth.

The Government's macroeconomic policy was outlined with the publication of the "Growth, Employment and Redistribution (GEAR)" report in 1996. This was supportive and broadly consistent with the latter neo-liberal approach, with a programme of fiscal restraint, privatisation and deregulation.

There has been much debate about why the ANC adopted such a stance, especially since it contrasted with its earlier policy statements and its general rhetoric during the liberation struggle. Despite the dire economic situation the ANC inherited after its resounding electoral victory in 1994 it still had room for maneouvre with respect to its economic policy. It had good physical infrastructure (for at least the bases for manufacturing), and foreign debt was low by international standards with no obligations towards any of the Bretton Woods institutions. As one commentator remarked "...compared to Russia, the challenges of economic transition [in South Africa] were less daunting since most basic institutions - like capital markets, a private banking system, justiciable contract law - were already firmly in place". ${ }^{8}$ It seems that, even though the IMF and World Bank did not have any official leverage over domestic policy makers, regular visits by senior officials and safari retreats made it quite clear to the new political elite that anything other than a neo-liberal agenda could result in downgrading of credit ratings and reductions in foreign investment.

\section{Socio-Economic Transition}

The impact of the GEAR policy has been disappointing - even in realizing its own stated macroeconomic goals. The rapid dismantling of tariffs has resulted in sharp declines in employment especially in the textile and manufacturing sector. On the other hand the initial depreciation of the currency has led to increases in some sectors such as tourism that have been partially reversed following more recent

8 Bratton \& Landsberg 1998, quoted in A. Habib and V. Padayachee, 'Economic policy and power relations in South Africa's transition to democracy', World Development, 28;3 (2000), 245-26. 
Figure 1a and $\mathbf{b}$. Official unemployment rates by population group and sex October 1996 and October 2001.
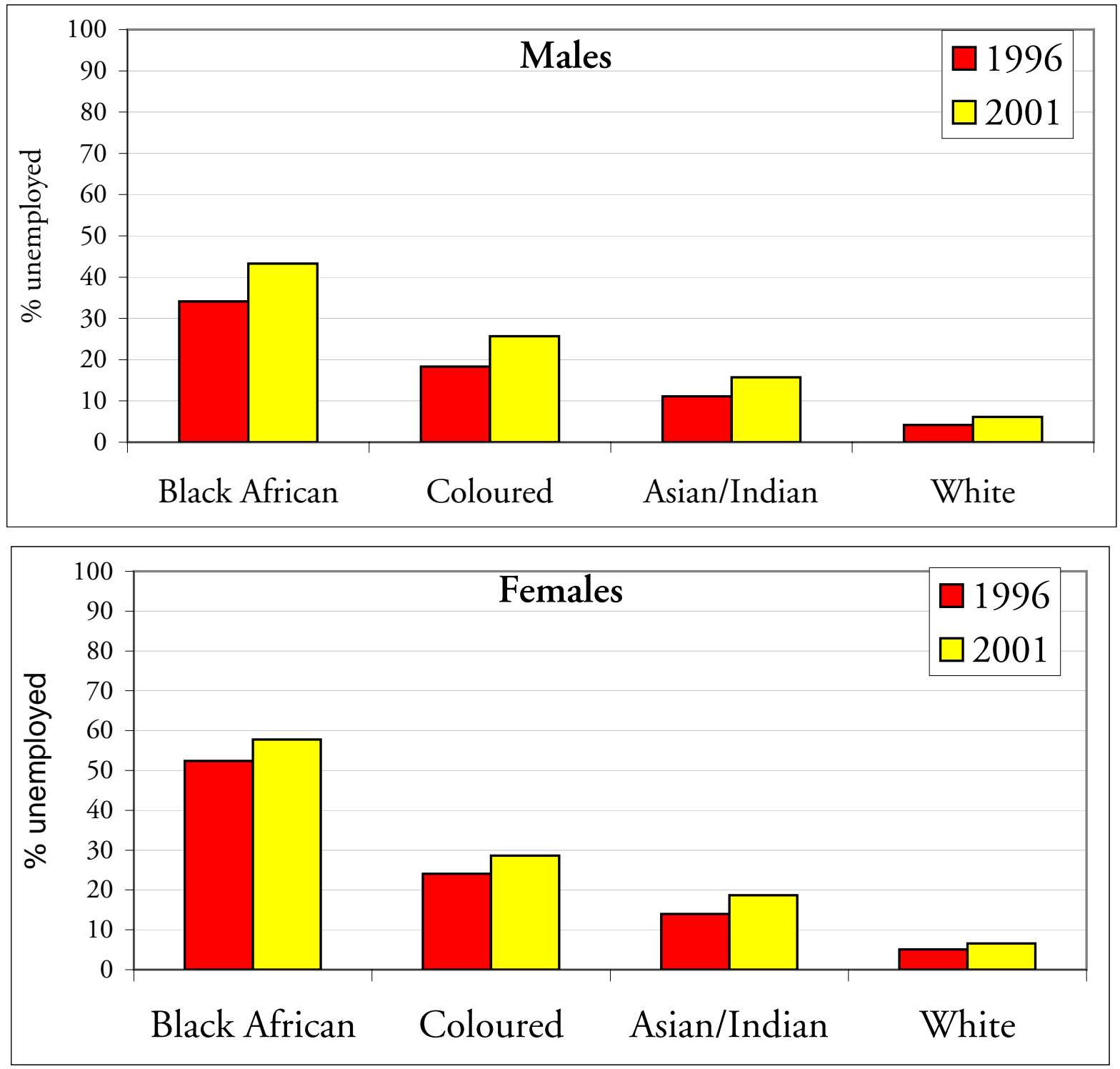

Source: Census 1996, 2001.

strengthening of the South African Rand. Overall it has been estimated that over 1 million jobs have been lost predominantly amongst the artisan and unskilled.

This has led to a significant growth in unemployment from 33.0\% in 1996 to $41 \%$ in $2001 .{ }^{9}$ This increase has disproportionately affected the majority African population with unemployment increasing from $42.5 \%$ to over $50 \%$ in just five years (figure 1). The loss of jobs in the formal sector is giving rise to so-called informal sector jobs. These include activities such as hawking, food retailing, home based manufacturing. In Cape Town alone the proportion of economically active people engaged in the informal sector has risen from 36\% in 1996 to 45\% in 2001.

9 StatsSA 2003. 
There is some debate as to whether this is an economically healthy development. The example of Silicon Valley is often cited as a way in which less regulated and smaller firms can achieve far greater flexibility in response to a global market. However, studies of most informal economies in Africa have shown that it is extremely difficult for small companies to grow without significant external inputs that in the present climate of reduced State investment is usually not forthcoming. In most cases the informal economy is a survival strategy rather than an engine for growth. $^{10}$

\section{Increases in Inequality}

Given the above changes it is not surprising to see that income inequalities have persisted: by 1995 the poorest $40 \%$ of households accounted for only $11 \%$ of the total income whilst the richest $10 \%$ commanded $40 \%$ of the total income. ${ }^{11}$ Perhaps contributing to a greater perception of exclusion amongst the African majority is that a small African minority is greatly benefiting from the transition period. The proportion of urban Africans in the richest quintile of the South African population increased five fold from 1990 to 1995 , rising from $2 \%$ to $10 \%$. This rise may well have been at the expense of the poor as the poorest $40 \%$ of the population have experienced a drop in their share of income. The level of income disparity between African households (as measured by the Gini Coefficient) rose from 0.3 in 1990 to 0.54 in 1998 (almost the same as the national figure of 0.58). ${ }^{12}$

In terms of basic facilities (table 1), data from the October Household Survey of 1999 indicates that $11 \%$ of the South African population lives in traditional type of housing and the highest proportion of such households occurs in the Eastern Cape (32\%) while the lowest proportions are in Gauteng, Western Cape and Northern Cape at less than $1 \%$. Nearly 1 in 6 of the population live in rudimentary shacks. The highest proportion is in rapidly growing urban areas such as Gauteng (25\%). Access to piped water inside the home appears to have got worse in the last few years and has dropped from $45 \%$ to $39 \%$. The percentage of households without a toilet was $12 \%$ in 1996 and had decreased to $10 \%$ by 1999 , but with large variations between the Provinces. Lastly, 22\% of the households in the survey reported hunger by the end of 1999. The highest proportion was identified in Mpumalanga (32\%),

10 Potter et al. 1999.

11 J. May Ed., Poverty and Inequality in South Africa: Meeting the Challenge (David Philip Publishers, Cape Town, Zed Books, London \& New York, 2000).

12 UNDP 2000. 
Table 1. House type, access to water and sanitation and food security,by province,1996-1999.

\begin{tabular}{lccccccc} 
Province & $\begin{array}{c}\text { House Type 1999 } \\
(\mathbf{N}=10851376)\end{array}$ & $\begin{array}{c}\text { \% households } \\
\text { with piped } \\
\text { water inside }\end{array}$ & $\begin{array}{c}\text { \% households } \\
\text { without toilet }\end{array}$ & $\begin{array}{c}\text { \% households } \\
\text { reporting } \\
\text { hunger }\end{array}$ \\
\cline { 2 - 7 } & \%traditional $^{\mathrm{a}}$ & \%shack $^{\mathrm{a}}$ & $\mathbf{1 9 9 6}^{\mathrm{b}}$ & $\mathbf{1 9 9 9}^{\mathrm{a}}$ & $\mathbf{1 9 9 6}^{\mathrm{b}}$ & $\mathbf{1 9 9 9}^{\mathrm{a}}$ & $\mathbf{1 9 9 9}^{\mathrm{a}}$ \\
\hline Eastern Cape & 31.9 & 12.1 & 24.7 & 23.4 & 29.1 & 25.1 & 30.9 \\
Free State & 7.0 & 19.4 & 40.6 & 29.9 & 8.8 & 5.3 & 23.8 \\
Gauteng & 0.2 & 24.7 & 67.7 & 58.8 & 2.5 & 0.8 & 14.7 \\
KwaZulu-Natal & 18.6 & 19.3 & 39.8 & 34.6 & 15.2 & 12.7 & 26.8 \\
Mpumalanga & 8.7 & 17.5 & 37.3 & 27.6 & 8.7 & 3.5 & 31.9 \\
Northern Cape & 0.9 & 12.9 & 50.0 & 48.1 & 10.7 & 10.7 & 15.1 \\
Northern & 15.2 & 6.2 & 17.8 & 12.1 & 21.2 & 18.8 & 15.5 \\
Province & & & & & & & \\
North West & 1.7 & 12.1 & 30.6 & 21.6 & 6.4 & 5.7 & 22.5 \\
Western Cape & 0.2 & 15.9 & 76.4 & 76.7 & 5.4 & 3.8 & 15.0 \\
South Africa & 10.9 & 16.9 & 44.7 & 38.8 & 12.4 & 9.7 & 21.9 \\
\hline
\end{tabular}

Source: a.1999 October Household Survey, b.1996 Census.

In summary South Africa is a stark example of what has been termed "combined and uneven development". ${ }^{13}$ This describes the process that has occurred in peripheral states that have been compelled by global capitalism to accelerate development of industrialization and urbanisation whilst retaining earlier modes of production. The amalgam of backward and advanced socio-economic conditions becomes the structural foundation for the combination of the different stages of development. South Africa is undergoing a protracted transition with almost half of the population living in rural traditional homesteads and engaging in declining subsistence production and relying increasingly on welfare payments, piece work and remitted wages; an ever increasing urbanized population that is either participating in 'a twilight zone of unregulated casual, informal, subcontracted and outsourced employment or is unemployed ${ }^{14}$; and a small elite of internationally skilled, professional and managerial employees. It should be noted that one of the significant changes since 1994 has been the rise of a black elite into the latter group through "economic empowerment" initiatives and deracialisation of state and

13 M. Löwy, The politics of combined and uneven development: The theory of permanent revolution (Verso Books, London, 1981).

14 N. Natrass and J. Seekings, 'Changing patterns in the South African labour market', in Post-Apartheid Southern Africa, ed. L. Petersson (London, Routeledge, 1998). 
parastatal bureaucracies. It is this socio-economic context that is required to explain the startling changes in health and mortality that is occurring in South Africa and to which we now turn our attention.

\section{Health and mortality}

\section{Health Transition Models}

The epidemiological transition was first described by Omran ${ }^{15}$ and referred to the complex long-term changes, (over decades or even centuries) in the patterns of health and disease as communities transform their social, economic and demographic structures. He posited a set sequence of events starting with a preponderance of infectious diseases, followed by an era when chronic diseases predominated. Communities adopting unhealthy lifestyles, which include smoking tobacco products, being physically inactive and consuming a typical westernised diet over time experience high levels of obesity, hypertension, diabetes and hyperlipidaemia in communities. This is seen to coincide with and be reinforced by the demographic transition. Further improving social and economic conditions lead to decreases in fertility and increases in life expectancy. Coupled with increasing industrialisation and urbanisation a decline occurs in infectious disease mortality mainly among the younger age groups. There is a consequent shift in the mortality profile towards chronic diseases.

It was anticipated that chronic diseases would increase in poor countries undergoing development, industrialisation and adoption of "western" lifestyles.

Initially, chronic diseases emerged in the wealthier sections of high income countries, however, by the last quarter of the 20th century these conditions occurred more frequently in the poor. On the basis of observations from some large middle-income populations Frenk and co-authors ${ }^{16}$ proposed a modification to Omran's theory with the protracted-polarised model of epidemiological transition. This model proposes the coexistence of infectious and chronic diseases in the same population and persisting over a long period. In the protracted - polarised model more affluent sections of the population would have completed the transition, while

15 A.Omran, 'The epidemiologic transition a theory of the epidemiology of population change', Millbank Memorial Fund Quarterly, 49 (1971), 509-538.

16 J. Frenk, J.L. Bobadilla, J. Sepúlveda and L.M. Cervantes, 'Health transition in middle-income countries: new challenges for health care', Health Policy and Planning, 4(1) (1989), 29-39. 
economically disadvantaged groups continue to suffer from pre-transitional pathologies. This epidemiological pattern reflects an economic and social situation of juxtaposition within the same society of a developed and an underdeveloped sector. In short, it is an expression, in terms of morbidity and mortality, of "combined and uneven development".

\section{Morbidity and Mortality}

The disease and death profile in South Africa predominantly reflects the protractedpolarised model, with infectious diseases affecting the poor, chronic diseases affecting both rich and poor and related to an urbanised lifestyle, and a large burden, particularly amongst the poor, of morbidity and mortality from trauma and violence. ${ }^{17}$ The poor suffer from all three patterns of mortality simultaneously. This section will present some of the data on causes of mortality and then highlight how the social and economic transition is specifically impacting upon the health of young men and women

Based on the 1996 South African death registration, infectious diseases together with maternal and malnutrition related conditions account for $30.6 \%$ of deaths and chronic diseases account for $31.9 \%$. Life expectancy in 1996 was 52.1 years for men and 61.6 years for women. ${ }^{18}$ Overall life expectancy has dropped from 63 in 1990 to 57 in 2000. It is estimated that premature adult mortality (measured as the probability of a 15 year old dying before the age of 60) has started increasing and will reach levels close to $80 \%$ within the next ten years making it one of the worst in the world.

Perhaps the most striking examples of the burden of disease caused by the persisting poverty and underdevelopment in large parts of South Africa are the high rates of infant and young child mortality. Table 2 highlights the differences between Provinces and race groups.

It should be noted that there is also a great deal of variation within Provinces. For example for the three to four million people who still live in the former Transkei Homeland area in Eastern Cape the IMR is 99 while in greater Cape Town, which houses three-quarters of the Western Cape population, IMR ranges from 15 in middle-class, mostly white suburbs to over 50 in black townships.

The poor are also afflicted with high levels of chronic disease morbidity such as diabetes, hypertension and strokes. Even in the poorest areas these diseases account for almost the same proportion of mortality as infectious diseases (figure 2).

17 Bradshaw, et al., 1995.

18 StatsSA 1998. 
Table 2. Infant and child mortality by province and population group, 1994-1998.

\begin{tabular}{lcc}
\hline Province & $\begin{array}{c}\text { Infant Mortality Rate } \\
\text { (per 1 } 000 \text { live births) }\end{array}$ & $\begin{array}{c}\text { Under-5 Mortality Rate } \\
\text { (per 1 000 live births) }\end{array}$ \\
\hline Eastern Cape & 61.2 & 80.5 \\
Free State & 53.0 & 72.0 \\
Gauteng & 36.3 & 45.3 \\
KwaZulu-Natal & 52.1 & 74.5 \\
Mpumalanga & 47.3 & 63.7 \\
Northern Cape & 41.8 & 55.5 \\
Northern Province & 37.2 & 52.3 \\
North West & 42.0 & 56.0 \\
Western Cape & 30.0 & 39.0 \\
Population Group & & \\
African & 47 & $*$ \\
Coloured & 18 & \\
Indian & $*$ & \\
White & 11.4 & \\
South Africa & 45 & \\
\hline
\end{tabular}

Source: National Department of Health 2001.

Data from mortuaries across the country suggest that about 15\% of all mortality is from non-natural causes. Most of these deaths are either homicides or motor vehicle accidents. A striking feature is the high number of fatalities for men. On the whole these are young men. With regard to non-fatal injuries, a study conducted in state hospitals in four cities in 1999 found that $61 \%$ of patients admitted to trauma units in these cities were alcohol positive with a mean alcohol level of $0.12 \mathrm{~g} / 100 \mathrm{ml}$. We need to give some ideas of what is "high". The study showed that $74 \%$ of violence cases, $54 \%$ of traffic collisions and $42 \%$ of trauma from other 'accidents' were alcohol positive. Across sites nearly $40 \%$ of trauma patients were positive for at least one drug $(29 \%$ cannabis, $11 \%$ Mandrax, $5 \%$ cocaine, $5 \%$ opiates, $0.3 \%$ methamphetamine and $0.2 \%$ amphetamine). ${ }^{19}$

Compounding all these statistics is the alarming rise of HIV/AIDS. The impact of this is reflected in massive increases in the mortality of young men and women during this transitional period (figures $3 \& 4$ ).

19 NIMMS 2000. 
Figure 2. Poor areas male years of life lost $(\mathrm{N}=446015)$.

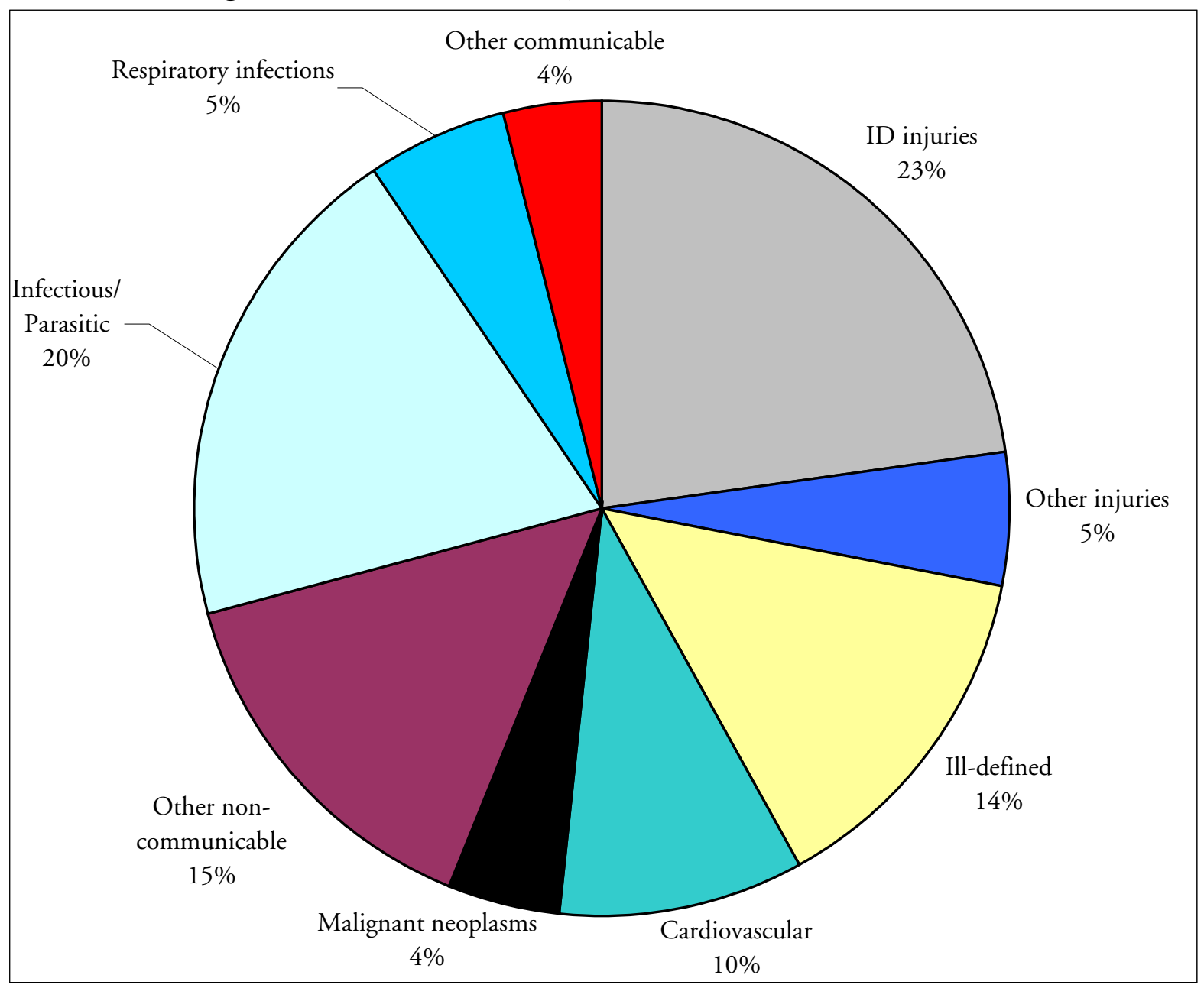

Source: Bradshaw \& Laubscher, 2002.

The disproportionate effect that transition is having on different age groups, especially young men, is shown in table 3 . This is reflected in the ratio of the number of deaths of young men as compared to that of older men. By 2000 it was the equivalent.

The remarkable rise in young male mortality has occurred despite a significant 'peace dividend' of reduced mortality from political violence, thanks to the transition to a democratic society (table 4). 
Figure 3. Changes in Male Mortality.

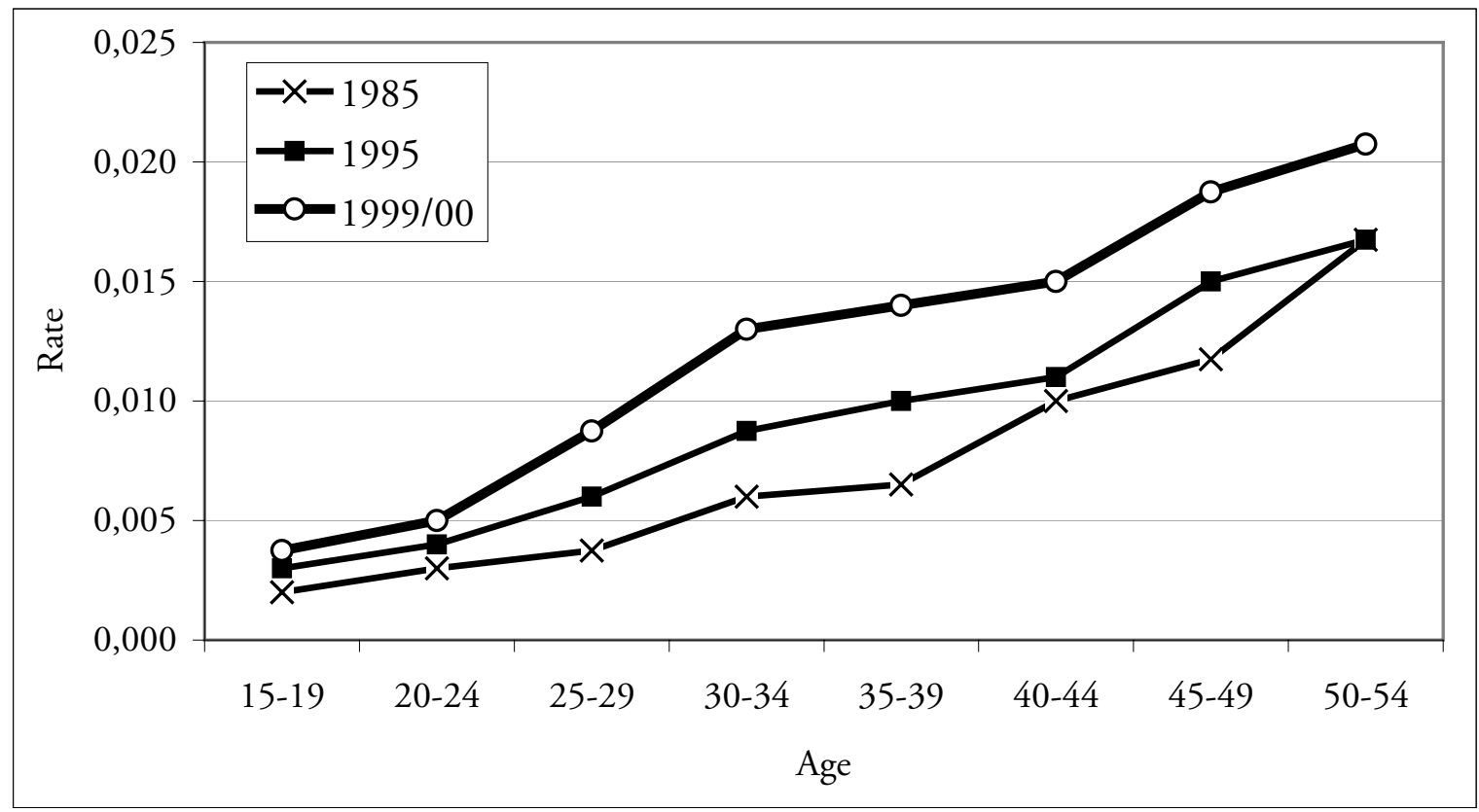

Figure 4. Changes in Female Mortality.

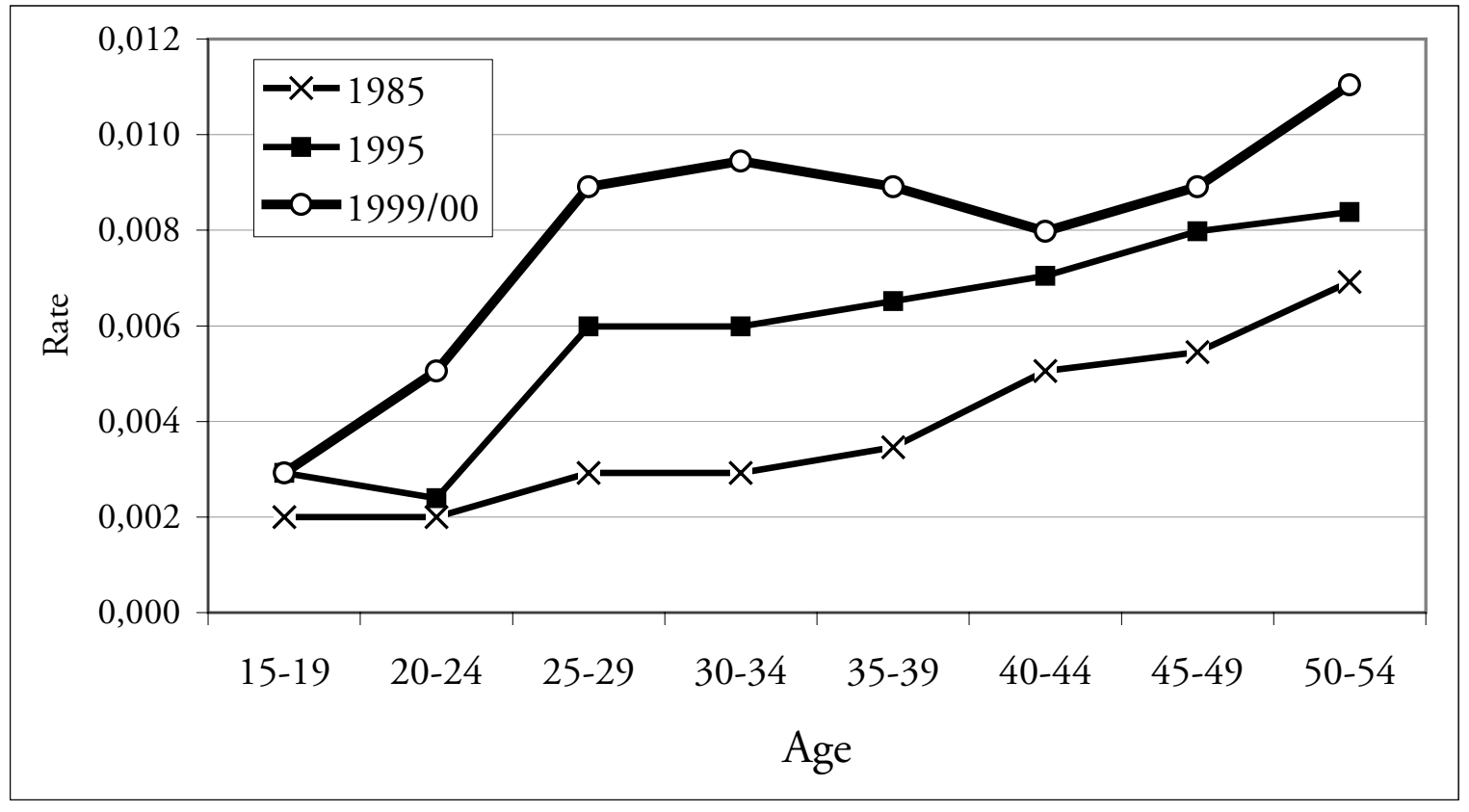

Source: Dorrington et al, 2001. 
Table 3. Ratio of deaths aged 15-49 to deaths aged 50+.

\begin{tabular}{ccc}
\hline Year & Female & Ratio \\
& 0.31 & Male \\
\hline 1990 & 0.37 & 0.66 \\
1993 & 0.47 & 0.73 \\
1996 & 0.57 & 0.82 \\
$1997 / 1998$ & 0.67 & 0.88 \\
$1998 / 1999$ & 0.78 & 0.97 \\
$1999 / 00$ & 1.00 \\
\hline
\end{tabular}

Source: Bradshaw, 1998.

Table 4. Deaths from political violence (including TVBC states).

\begin{tabular}{cc}
\hline Year & Number of Deaths due to Political Violence \\
\hline 1985 & 879 \\
1987 & 661 \\
1989 & 1403 \\
1991 & 2706 \\
1993 & 3794 \\
1995 & 1044 \\
1997 & 470 \\
\hline
\end{tabular}

Source: Bradshaw, 1998.

\section{The Case of Cape Town}

We now turn to examining more closely the interaction between the social and political transition and mortality through a more in-depth analysis of changes occurring in Cape Town.

Cape Town is situated on the south-western tip of South Africa and is home to about 3.5 million people. It is the third largest city in South Africa, following Johannesburg and Durban. Table Mountain and the spectacular Cape Peninsula are central to Cape Town's beauty, which harbours a vibrant cultural mixture of people. A large part of the less affluent population lives on the lower plains called the Cape Flats, which were relatively unpopulated until the 1960s. Since then two 
major waves of human settlement have taken place: after the 1960s forceful resettlement of so-called 'coloured' people by the apartheid government; and in the 1980s, when a then illegal process of large-scale African migration started from extremely impoverished areas of the Eastern Cape. At present, the area of Khayelitsha and Greater Nyanga accommodates about three quarter of a million people. In combination, apartheid spatial planning and strong migratory push factors contribute to the growing urban sprawl of the Greater Cape Town and the expansion of its highly racialised economic geographies. Whilst it has unique demographic and historical features the rapid growth, especially of the poor African townships, with the concomitant social, economic and political challenges make the issues facing Cape Town similar to other cities in South Africa.

\section{Health Patterns Across the City}

Total mortality varies across the City. The two districts with the highest concentration of poor African population, Khayelitsha and Nyanga, experience the greatest mortality. This difference is accentuated if we focus upon premature mortality as measured by Years of Life Lost (YLL). This is of particular interest to public health managers who work to avoid premature and preventable mortality. The average YYL in the City is 11,178 if Nyanga and Khayelitsha are excluded. This is almost half the premature mortality experienced by Nyanga $(20,502)$ and Khayelitsha $(18,974)$.

To understand the causes of premature mortality better, a review of the distribution of causes of mortality in each subdistrict is helpful. It appears that the disproportionate burden of premature mortality in Nyanga and Khayelitsha is as a result of high levels of infectious disease, injuries, road traffic accidents and homicide. The age standardised mortality rate (per 100000$)$ for infectious diseases is highest in Khayelitsha (266) and Nyanga (221) and lowest in Blaauwberg (58), South Peninsula (84) and Tygerberg East (92). The responsibility for addressing this inequity must rest firmly with the City government authorities, as the provider of basic services: water, sanitation and housing. Inadequate provision of water and sanitation is largely responsible for gastrointestinal infections and overcrowded housing allows the spread of respiratory infections such as tuberculosis. Maternal deaths are preventable if there is access to a good quality health service. One thing C.T. has is a good primary level maternity service, which is well-linked to higher levels. The burden of HIV is once again borne predominantly by Khayelitsha and Nyanga. 
Figure 5. Non-communicable age standardized deaths per 100.000 persons in 2001.

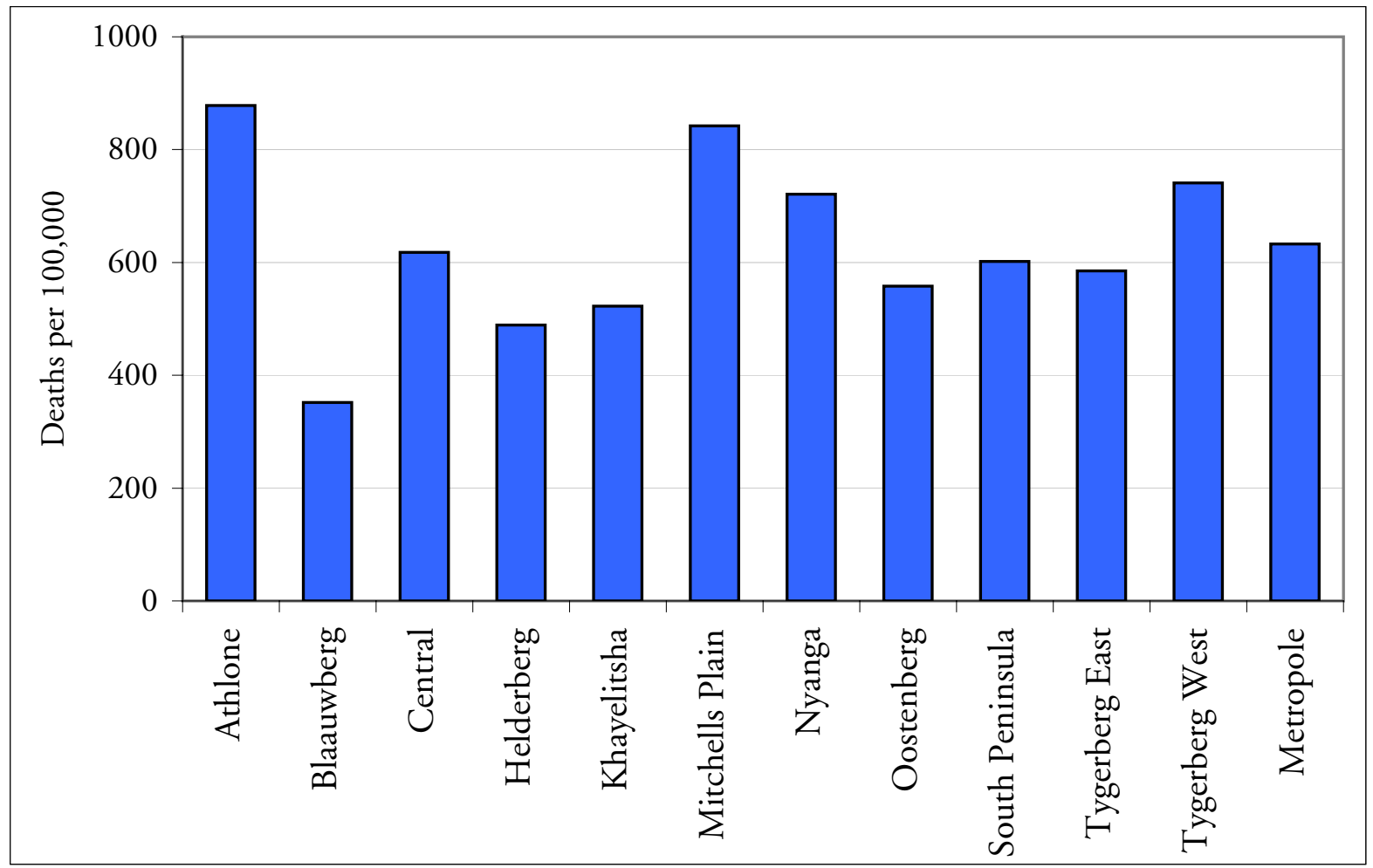

Source: Groenwald et al, 2003.

A slightly different pattern emerges for mortality from non communicable disease (figure 5). The levels remain high in the poorest districts but are highest in districts such as Athlone and Mitchells Plain that rank just above the poorest districts. This reflects the increased prevalence of risk factors such as hypertension, smoking and diabetes in these poor communities compared with wealthier districts.

This pattern of mortality can only be understood in the context of the underlying structural determinants of mortality and the how the dynamic of integration into a global economy is influencing these determinants.

\section{Economic Insecurity}

The uniqueness of the Cape Town urban sprawl is not restricted to the recent and very rapid population growth, but also reflects the melting pot of extremes. It is a polarised city where affluent suburbs and economic centres present a stark contrast to the overcrowded, impoverished township communities. A recent survey of over 1500 households in the townships by the School of Public Health and PLAAS at the University of the Western Cape found that two thirds (67 percent) of wage earners do not earn enough to push their household above the poverty line, making them the 'chronic working poor', and half of breadwinners (52 percent) receive less than the minimum wage per month $(\$ 120)$. In addition to earning low wages in 
general, the income stability of those households with employment is very precarious. For example, in 32 percent of households the main breadwinner had lost his/her job at some point during the last year, and 31 percent of households suffered the permanent loss of a full-time job during the last 5 years.

\section{Lack of Infrastructure}

Apart from the obvious handicaps such as lower education and skill levels (mostly due to the appalling quality of schooling in rural and poor urban areas), the spatial isolation of most poor African inhabitants is an often forgotten barrier to employment . Forty percent of main breadwinners take more than one hour to get to work. For $60 \%$ of breadwinners, a return journey to work exceeds R20 (\$3) per trip. A recent report found that the poor in Cape Town have to commute an average of $16 \mathrm{~km}$ to work compared with $12 \mathrm{~km}$ for the rich. ${ }^{20}$

This reflects the inability of the city administration to instigate significant changes in the social and economic distribution across the city. Turok ${ }^{21}$ highlights how the pressures to become a global city which attracts foreign investment and tourism has severely limited the progress towards urban integration. Despite an extensive and widely publicized process of identifying development nodes that are situated closer to the areas that have concentrations of the poor, nearly all private investment has continued to flow to the richer suburbs. This is largely due to the reluctance and inability of local government to influence market forces - 'the general implication is that income, social class and market forces have replaced race and state control in directing the pattern of urban development'. Cape Town has been hit hard by the lowering on tariffs especially in the textile industry, with significant job losses. This is accelerating the growth of the informal economy. In $199635 \%$ of economically active people were engaged in this sector; this had risen to $45 \%$ by 2001 . $^{23}$

There is presently a backlog of about 220,000 houses and it is increasing by 30,000-50,000 per annum. ${ }^{24}$ Yet at the same time housing resources allocated by central Government to Cape Town are decreasing as it is deemed less needy than other Provinces. Furthermore, Jenkins and Wilkinson ${ }^{25}$ show that the ability of public investment to offset this is being compromised by pressure to cut expenditure especially in human resources. Often this is leading to the building of

20 CMC 1999.

21 Turok 2001.

22 Turok 2001 p. 2362.

23 CMC 2002.

24 Cape Metropolitan Housing Task Team 1999.

25 Jenkins and Wilkinson 2001. 
sports halls and community centers that remain closed because of a lack of personal and operating costs. Finally, MacDonald et al. ${ }^{26}$ provide compelling evidence of how the pressure for local government to become more 'entrepreneurial' is leading to privatization and escalating costs of basic services such as water and sanitation, and increasing number of cut-offs because of non-payment in the poorer parts of the city.

\section{Men's health in South Africa and historical parallels}

Understandably, in the "new" South Africa much of the focus in terms of health outcomes, and policies and programmes to address these has been our children and young women. It is clear, however, from the above, that the burden of mortality and morbidity experienced by particularly those from poor communities, is massive and increasing as a result mainly of HIV/AIDS and T.B., trauma and violence and substance abuse, especially alcohol. Men's health, which has been relatively neglected, but has recently become a topic of interest and activity in rich countries, is clearly of critical importance - both in its own right and in relation to economic productivity - in middle-income countries such as South Africa.

The fact that stark and disturbing trends in men's health are manifesting in South Africa's protracted-polarised epidemiological transition is, at first sight, surprising. After all, in developing countries is it not primarily men who all enjoy fully employment, better education and the fruits of urban living? While these social descriptors are indeed valid and reflect real phenomena, historical demography has shown that rapid social change associated with capitalist industrialization carries with it serious heath hazards, especially for men. The best documented studies are of early industrial Sweden and England/Britain. Both provide useful insights for South Africa.

Sundin and Willner ${ }^{27}$ note a significant surplus male mortality in early nineteenth century Sweden: "Compared with women of the same age, the male surplus mortality existed for almost all of the contemporary registered causes of death. Among the most striking differences were deaths related to excessive alcohol consumption, accidents and violent deaths, suicides and tuberculosis. There was an urban/rural surplus of mortality for both sexes, but male urban mortality and the urban male/female surplus was particularly high. As has often been the case over time and space, married persons had the lowest figures within their respective sex.

26 MacDonald et al. 2003.

27 J. Sundin and S. Willner, 'Health and social transitions: The Swedish case'. Draft Paper for PHOENIX/MMF Workshop quoted with permission, (2002). 
Local studies in areas where the proletarianisation had started indicate that men in the lowest social strata had the highest mortality figures, while the social gradient was not visible to the same extent among women. Consequently, the highest mortality risks existed among urban unskilled male workers without a wife at their side. These variations over time, space, class and between persons with different marital status means that the male/female differences cannot be explained by simple biological factors."

In their enquiry Sundin \& Willner ask: "Why was the male surplus mortality primarily an urban phenomenon and why was it so high during the first half of the nineteenth century?" Their fascinating exploration attributes this phenomenon to a combination of linked factors associated with rapid and disorganized urbanization, namely, a lack of social networks of kin and neighbours leading to greater vulnerability, heavy consumption of alcohol with its associated negative impacts both on resources for food, housing etc. and associated accidents and violent trauma. ${ }^{28}$

Szreter $^{29}$ in his work on nineteenth century Britain describes a similar process of unprecedented rapid economic growth and urbanization between 1820 and 1870, accompanied by rising mortality rates and stagnating life expectancy. The increased incidence of infectious diseases was "indicative of a breakdown in the second quarter of the $19^{\text {th }}$ century in urban administration and environmental health services." " Szreter suggests that: "in the fast-growing industrial towns of Britain in the first half of the $19^{\text {th }}$ century, environmental deterioration occurred through a configuration of three socially divisive forces, which were themselves intimately related to, indeed entailments of Britain's free-market pattern of economic growth. Firstly, inequality of incomes and wealth was growing apace, through the processes of capital accumulation, the seizing by an energetic and fortunate few of commercial opportunities and the extraction of rents of various kinds. ${ }^{31}$ Secondly, the industrial town was continually receiving rural in-migrants, often in great surges during times of depression. ${ }^{32}$ The in-migrants - all rural newcomers to the city and many of them Irish - tended to fill the least secure and lowest-paid jobs available." ${ }^{33}$

28 Sundin and Willner, (2002), p.10.

29 S. Szreter, 'Rapid economic growth and the 'four Ds' of disruption, deprivation, disease and death: public health lessons from nineteenth century Britain for twenty-first century China?', Tropical Medicine and International Health, 4(2) (1999), 146-152.

30 Szreter (1999), p.147.

31 H. Phelps Brown, Egalitarianism and the Generation of inequality (Oxford University Press, Oxford, 1988).

32 M.A. Andersen, Family structure in Nineteenth Century Lancashire (Cambridge, 1971); C. Pooley and S. D'Cruze, 'Migration and urbanisation in North West England circa 17601830', Social History, 19 (1994), 339-358.

33 Szreter (1999), p.147. 
Szreter provides also a third explanation for these health declines, namely residential segregation or "suburbanisation".

However, suggests Szreter, these three forces alone were not responsible for the deprivation, disease and death in Britain's industrializing cities. He attributes the lack of an effective political and administrative response at national and local government level to these environmental problems to what he terms "disruption". As a result of rapid economic growth, which, he suggests: "entails the disruption of established social relations, ideologies and structures of authority; this created political and administrative paralysis in Britain's industrial cities". ${ }^{34}$ In addition to the important role of the state in provision and regulation of social benefits welfare and environmental - Szreter invokes a more decentralized conception of "the state", embracing 'civil society', especially local government and the public service professions.

Szreter proposes that "to promote economic success and to avoid public disquiet over the health and welfare costs borne by many citizens in a growing 'market' economy, there needs to be careful attention to investment in the institutions of trust and communication which sustain 'social capital' or civic participation". 35

In summary, then, the historical examples of industrializing Britain and Sweden exhibit strong parallels with South Africa, both in terms of its high mortality which increasingly affects young men - and in terms of its rapid and squalid urbanization with accompanying disruption of social services and networks and declining social capital.

\section{Prospects for men's health in South Africa}

In both Britain and Sweden, the organic growth and spread of industrial capitalism and increasing intervention by the state in social provisioning, resulted in gradually improving working and living conditions - albeit differentially for different social groups - and with that the long, slow and substantial improvement of the health of their populations, including that of young men. What are the prospects then for global health improvement in South Africa, and, in particular, for young men's health? Can it be anticipated that the British and Swedish models will be "automatically" replicated by South Africa? Will an epidemiological transition occur?

In our view this prospect is extremely unlikely, unless the current social and economic dispensation is fundamentally reformed. For the present pattern of

34 Szreter (1999), p.148.

35 Szreter (1999), p.151. 
economic globalisation, which appears to be entrenching a situation of "Combined and uneven development" both globally and in middle-income countries like South Africa, is propelling continuing disorganised, squalid and dangerous urbanisation. And it is into this maelstrom that young men are being driven from the destitute countryside to encounter the hazards of housing insecurity, dangerous informal employment, plentiful alcohol and cheap and risky sex. And the relative absence of social capital of all types - linking, bridging and bonding - in these situations renders and will continue to render this group highly vulnerable to morbidity and mortality.

Professor David Sanders and Dr Mickey Chopra, School of Public Health, University of the Western Cape, Bellville, 7535, South Africa. 


\section{References}

Andersen M. A., Family structure in Nineteenth Century Lancashire (Cambridge, 1971).

Bradshaw D., Health for All - Monitoring Equity. South African Health Review 1998. (Health Systems Trust, Durban, 1998).

Bradshaw D. and R. Laubscher, 'Mortality profile of the rich and the poor', in Poverty and chronic diseases in South Africa, eds. Bradshaw D, Steyn K (Cape Town, MRC, 2002).

Cape Metropolitan Housing Task Team (1999). Statement of intent with regard to housing in CMA. CMC, Cape Town.

Cape Town Metropolitan Council (2002). Economic trends and spatial patterns in the Cape Metropolitan area: Update. CMC, Cape Town.

Dorrington, R., Bourne, D., Bradshaw, D., Laubscher, R. \& Timaeus I.M, The impact of HIVIAIDS on adult mortality in South Africa. Technical Report. Burden of Disease Research Unit. (Cape Town, Medical Research Council, 2001).

Frenk, J., Bobadilla, J. L., Sepúlveda, J. and Cervantes, L. M. 'Health transition in middle-income countries: new challenges for health care', Health Policy and Planning, 4(1) (1989), 29-39.

Friedman S., 'The Struggle within the Struggle: South African resistence strategies', Transformation, No. 3, (Durban, 1987).

Gelb S., South Africa's economic crisis (London, Zed Books, 1991).

Habib A. and Padayachee V., 'Economic policy and power relations in South Africa's transition to democracy', World Development, 28;3 (2000), 245-263.

Jenkins P. and Wilkinson P. 'Assessing the increasing impact of global economy on urban development in South African cities', Cities 19 (2001), 33-47.

Löwy M., The politics of combined and uneven development: The theory of permanent revolution (Verso Books, London, 1981).

McDonald D. A., 'No Momey, No Service: South Africa's Poorest Citizens Lose Out Under Attempts to Recover Service Costs for Water and Power', Alternatives 28 (2002).

Marais H., South Africa: Limits to change - the political economy of transformation (Cape Town, UCT Presss, 1998).

May J,. Ed. Poverty and Inequality in South Africa: Meeting the Challenge (David Philip Publishers, Cape Town. Zed Books, London \& New York, 2000).

McGarth M., 'Economic growth, income distribution and social change' in The Political Economy of South Africa, eds. Natrass N \& Ardington E (Cape Town, 
Oxford University Press, 1990).

Natrass N. and Seekings J., 'Changing patterns in the South African labour market', in Post-Apartheid Southern Africa, ed. Petersson L (London, Routeledge, 1998).

NIMSS (2002), A profile of fatal injuries in South Africa: Fourth Annual Report of the National Injury Mortality Surveillance System 2002.

[http://www.sahealthinfo.org/violence/nimssannual2002.htm]

Omran, A., 'The epidemiologic transition a theory of the epidemiology of population change', Millbank Memorial Fund Quarterly, 49 (1971), 509-538.

Parry C. D. H., and Peden M. M, 'Alcohol-related mortality and morbidity in South Africa'. Paper presented at the joint meeting of the WHO Management of Substance Dependence and Violence \& Injuries Prevention Units on The social consequences of alcohol use: Establishing and monitoring alcohol's involvement in casualties. Prague (Czech Republic), (2000).

Phelps Brown H., Egalitarianism and the Generation of inequality (Oxford University Press, Oxford, 1988).

Pooley C. and D'Cruze S., 'Migration and urbanisation in North West England circa 1760-1830', Social History, 19, (1994), 339-358.

Statistics South Africa. The People of South Africa Population Census, 1996. Census in Brief. Report No 03-01-11(1996). Statistics South Africa. Pretoria.

Statistics South Africa. October Household Survey 1999. Statistical Release P0317. [http://www.statssa.gov.za/Statistical_releases/Statistical_releases.htm].

Statistics South Africa. The People of South Africa Population Census,2000. Census in Brief. Report (2003). Statistics South Africa. Pretoria.

Sundin J. and Willner S., 'Health and social transitions: The Swedish case'. Draft Paper for PHOENIX/MMF Workshop quoted with permission (2002).

Szreter S., 'Rapid economic growth and the 'four Ds' of disruption, deprivation, disease and death: public health lessons from nineteenth century Britain for twenty-first century China?', Tropical Medicine and International Health, 4(1999):146-152.

Turok I., 'Persistent polarisation post-Apartheid? Progress towards urban integration in Cape Town', Urban Studies, 384(2001):2349-2377.

United Nations Development Program (2000), South Africa: Human Development Report 2000. [http://www.undp.org.za/SADR2000.htm].

Van Zyl Slabbert F., The quest for democracy: South Africa in transition (London, Penguin Books, 1992). 